\title{
TU/e EN⿴HONE

\section{Grid modernization efforts in the USA and Brazil : some common lessons based on the smart grid initiative}

\section{Citation for published version (APA):}

Suryanarayanan, S., Ribeiro, P. F., \& Simões, M. G. (2010). Grid modernization efforts in the USA and Brazil : some common lessons based on the smart grid initiative. In Proceedings of the 2010 IEEE Power and Energy Society General Meeting, 25-29 July 2010, Minneapolis, Minnesota (pp. 1-5). Institute of Electrical and Electronics Engineers. https://doi.org/10.1109/PES.2010.5590186

DOI:

10.1109/PES.2010.5590186

Document status and date:

Published: 01/01/2010

\section{Document Version:}

Publisher's PDF, also known as Version of Record (includes final page, issue and volume numbers)

\section{Please check the document version of this publication:}

- A submitted manuscript is the version of the article upon submission and before peer-review. There can be important differences between the submitted version and the official published version of record. People interested in the research are advised to contact the author for the final version of the publication, or visit the $\mathrm{DOI}$ to the publisher's website.

- The final author version and the galley proof are versions of the publication after peer review.

- The final published version features the final layout of the paper including the volume, issue and page numbers.

Link to publication

\section{General rights}

Copyright and moral rights for the publications made accessible in the public portal are retained by the authors and/or other copyright owners and it is a condition of accessing publications that users recognise and abide by the legal requirements associated with these rights.

- Users may download and print one copy of any publication from the public portal for the purpose of private study or research.

- You may not further distribute the material or use it for any profit-making activity or commercial gain

- You may freely distribute the URL identifying the publication in the public portal.

If the publication is distributed under the terms of Article 25fa of the Dutch Copyright Act, indicated by the "Taverne" license above, please follow below link for the End User Agreement:

www.tue.nl/taverne

Take down policy

If you believe that this document breaches copyright please contact us at:

openaccess@tue.nl

providing details and we will investigate your claim. 


\title{
Grid Modernization Efforts in the USA and Brazil - Some Common Lessons Based on the Smart Grid Initiative
}

\author{
Siddharth Suryanarayanan, Senior Member, IEEE, Paulo F. Ribeiro, Fellow, IEEE, and M. Godoy \\ Simões, Senior Member, IEEE
}

\begin{abstract}
This paper presents some comparisons between the trends in electricity infrastructure growth in the United States and Brazil, and attempts to identify commonalities and differences on grid modernization efforts in these two countries using the Smart Grid Initiative as a template.
\end{abstract}

Index Terms-Brazil, Energy Independence and Security Act of 2007 (EISA07), grid modernization, Smart Grid Initiative, transmission infrastructure, USA.

\section{INTRODUCTION}

$\mathrm{O}$ $\mathrm{N}$ November 10, 2009, the Brazilian electricity grid encountered a massive blackout that left several tens of millions of people without electricity supply for several hours [1]. While the causes of this blackout are still under investigation at the time of writing this paper, its impact has been significantly reported [2]. The extent of the Brazilian blackout of 2009 and its economic impact is reminiscent of the 2003 blackout of the northeastern grid in the US - though the former event may not be as dramatic as the latter event vis-àvis the total loss of generation in MW [1], [3]. It might be conjectured that the latter event was mainly responsible for the various grid modernization initiatives and legislations in the US since 2003- the most significant of which is the Smart Grid Initiative, which occurs in the Energy Independence and Security Act of 2007 (EISA07) as the official policy of modernizing the US transmission and distribution grid [4]. The US Department of Energy (DoE) characterizes a Smart Grid as one with the following characteristics: 1) ability to perform self-healing and operate resiliently against cyber and physical attacks; 2) enabling active participation of consumers in demand response; 3 ) catering to the power quality needs of the $21^{\text {st }}$ century loads; 4) incorporating renewable resources and energy storage along with conventional installations; 5) optimizing assets for efficient operation and 6) enabling new services, products, and markets aided by interoperable standards and lowered barriers [5]. The Smart Grid Initiative

This work was supported in part by the U.S. National Science Foundation under Grant 0757956 and in part by the Power Systems Engineering Research Center (PSERC) under Grant T-41.

S. Suryanarayanan and M. G. Simões are with the Division of Engineering, Colorado School of Mines, Golden, CO 80401 USA (e-mails: Sid.suryanarayanan@ieee.org, Msimoes@mines.edu).

P. F. Ribeiro is with the Engineering Department, Calvin College, Grand Rapids, MI 49546 USA (e-mail: Pribeiro@calvin.edu). is expected to hasten the deployments of renewable energy resources in the US grid to wean off the use of fossil fuels for electricity generation and is aimed at increasing the reliability and security of the electricity grid. This initiative is also expected to impact the end users by providing them an avenue for active participation in demand response.

At a time when several significant steps are being launched in the US for modernization of the electricity infrastructure as part of the landmark Smart Grid Initiative, it might be worthwhile to draw some comparisons between the recommendations of that initiative and the grid modernization efforts in Brazil. The intent of such a comparison is to probe the usefulness of the recommendations of the Smart Grid Initiative for grid modernization in a developing country with increased energy needs like Brazil.

The scope of this paper does not include detailed analysis of the blackout events of 2003 and 2009, in North America and Brazil, respectively. Instead, this paper will briefly address the trend in electricity infrastructure growth and challenges in the US and in Brazil and present some commonalities and differences between the grid modernization efforts therein under the purview of the Smart Grid Initiative.

\section{COMPARISON OF TRENDS IN ELECTRICITY INFRASTRUCTURE GROWTH BETWEEN THE US AND BRAZIL}

\section{A. Electricity infrastructure growth in the US (2009-2030)}

The demand for electric energy in the US is projected to grow at an annual rate of approximately 1\% from 2009 to 2030; thus, raising the actual consumption from approximately 3764 Billion $\mathrm{kWh}$ to approximately 4748 Billion $\mathrm{kWh}$ in that timeframe, as shown in Figure 1, which is generated using data obtained from [6].

Concomitantly, the growth of generation in the form of new installed capacity in the US is expected to grow by $260 \mathrm{GW}$ as shown in Figure 2, which is also generated using data obtained from [6]. It is noted that this growth of generation capacity also accounts for approximately $30 \mathrm{GW}$ in capacity retirements. Of this new additional capacity, almost $25 \%$ is expected to come from renewable resources; $18 \%$ is projected to use coal and approximately $5 \%$ is projected to use nuclear as the fuel; and almost $53 \%$ of the new additions is expected to use natural gas as a fuel source. 


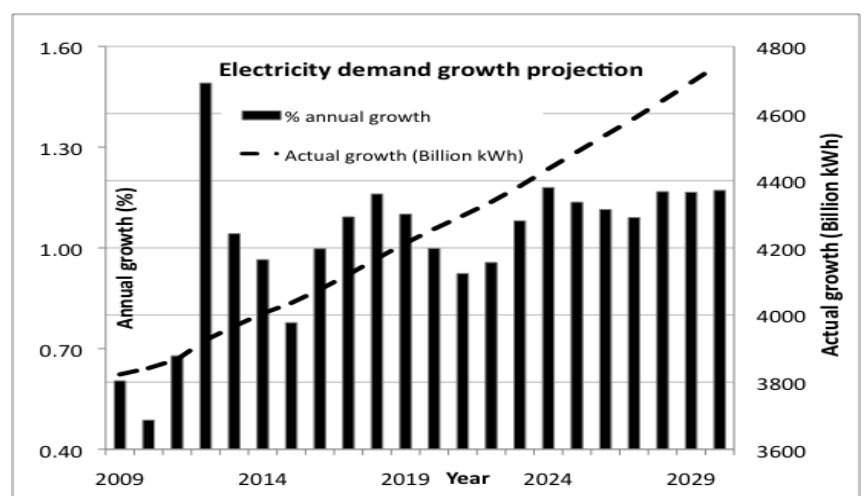

Figure 1. Trend in electricity demand growth in the US (figure generated using data obtained from [6]).

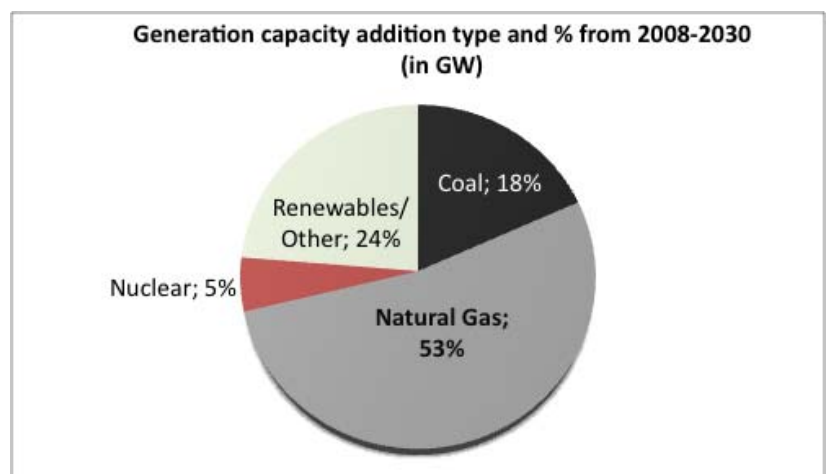

Figure 2. Type and percentage of generation capacity addition from 2008 to 2030 in the US (figure generated using data obtained from [6]).

Electricity generation from wind installations in the US is expected to grow from a projected value of 36.35 billion $\mathrm{KWh}$ in 2009 to 129.8 billion $\mathrm{kWh}$ in 2030 at an annual rate of $6.25 \%$ [6]. This growth in wind energy installations in the US is heavily dependent on state regulations such as wind profile at the location, cost of energy from fossil fuels, ability to access the transmission system, investments in transmission infrastructures, availability of energy storage deployments, and state mandates such as renewable portfolio standards [6].

However, the backbone of the electricity infrastructure in the US, i.e., the transmission grid is suffering from: 1) stagnating and declining investments, [7], and 2) aging assets, [8]. A particularly significant challenge for transmission system growth in the US is related to the interstate regulations for planning, siting, and allocating costs [9]. Locating sites for new grid infrastructure is considered the most significant obstacle for maximizing the reach of expanding renewable resources [10]. Given these challenges in the transmission system in the US, it is apparent that most of the recommendations of the Smart Grid Initiative may be realized in the electric distribution side of the electricity delivery infrastructure [11].

\section{B. Electricity infrastructure growth in Brazil (2009-2030)}

Brazil is the fifth largest country in the world with an area of 8.5 million sq. $\mathrm{km}$ that is inhabited by approximately 199 million people who consumed 404.3 billion $\mathrm{kWh}$ of electricity in 2007. It is pertinent to draw comparison to the US, which is has an area of 9.8 million sq $\mathrm{km}$ with a population of 307 million that consumed more than 3800 billion $\mathrm{kWh}$ in 2008 [12]. Brazil produced 438.8 billion $\mathrm{kWh}$ of electricity in 2007 (approximately $80 \%$ of which was generated using hydropower) compared to the US which, as the largest producer and consumer of electricity in the world, produced 4110 billion $\mathrm{kWh}$ in 2008 [12]. Brazil also imported approximately 42 billion $\mathrm{kWh}$ of electric energy in 2008 to meet its demands. In keeping with the development of Brazil and the projected growth in most of its economic sectors, the electricity demand growth in Brazil is expected to grow at a steady rate of $4.8 \%$ until 2020 as shown in Figure 3 to a total of approximately 700 Billion $\mathrm{kWh}[13]$.

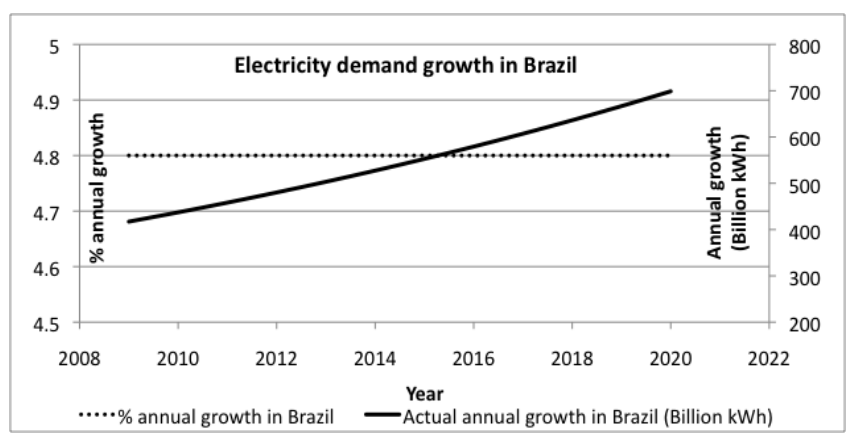

Figure 3. Trend of electricity demand growth in Brazil from 2009 to 2020 (generated using data from [13]).

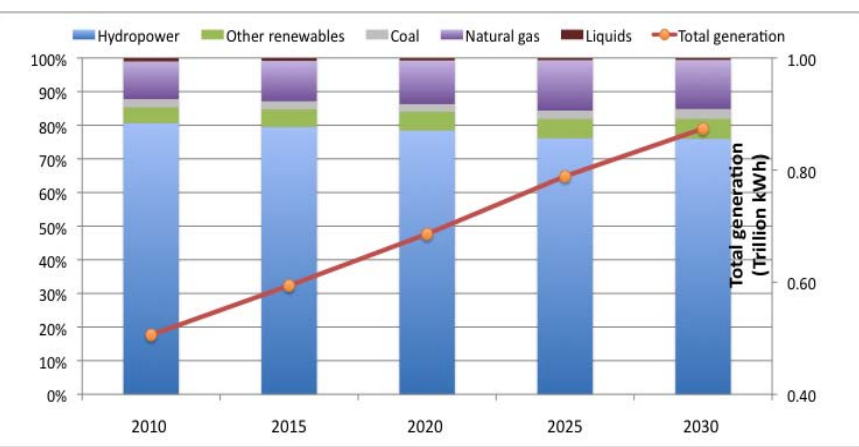

Figure 4. Trend in generation capacity addition in Brazil during 2010-2030 (figure generated with data from [14]).

Generation capacity addition in Brazil is expected to follow the trend shown in Figure 4 for the period 2010 to 2030 in order to cater to the projected increase in demand [14]. From Figure 4 , it is apparent that there is a concerted effort to decrease the reliance on hydropower in Brazil for serving the electricity demand from approximately $84 \%$ in 2010 to approximately $78 \%$ in 2030 [14]. This effort is planned in order to tide over times of severe drought in Brazil such as in 2001 [15]. The total installed capacity of nuclear-fueled generation in Brazil is expected to increase from $2000 \mathrm{MW}$ in 2006 to $7500 \mathrm{MW}$ in 2030 [16]. Among the non-hydro renewable resources in Brazil, wind energy appears the most credible choice and is projected to grow at an annual rate of $14.8 \%$ from approximately 375 million $\mathrm{kWh}$ in 2006 to 6890 million $\mathrm{kWh}$ in 2030 [14]. Figure 5 depicts some potential locations of new wind energy installations in Brazil. Figure 6 
depicts a timeline of some of the generation capacity additions in Brazil in the short term.

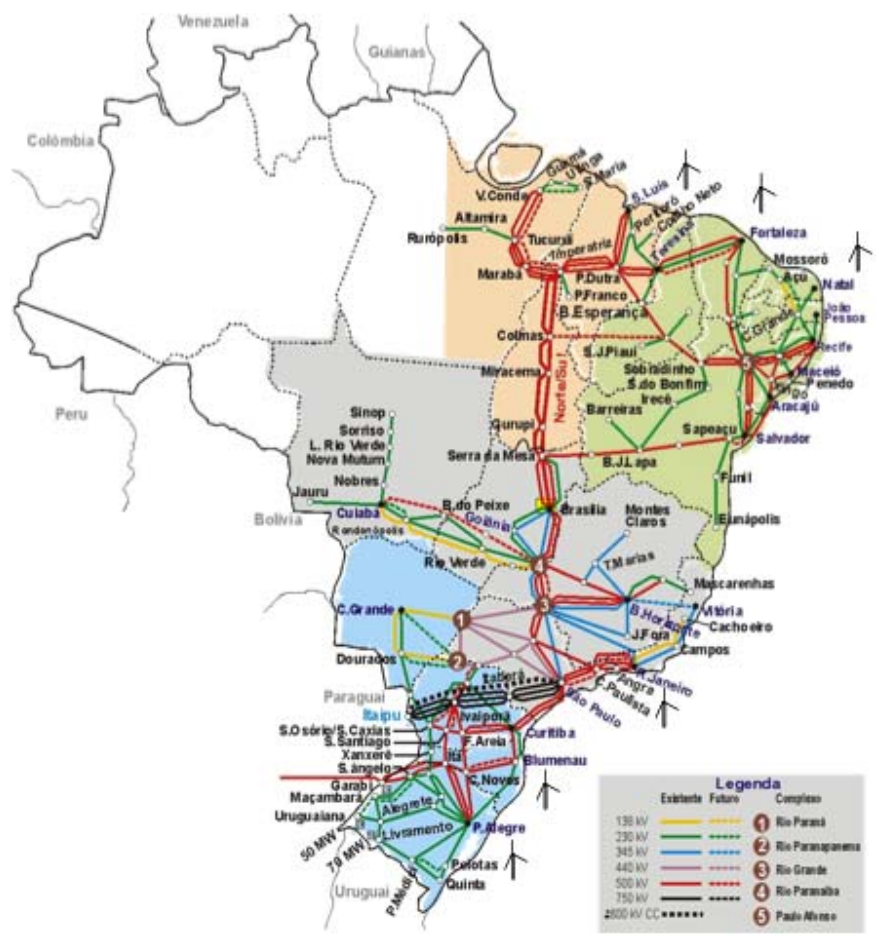

Figure 5. Possible locations of wind energy projects in Brazil (courtesy: Operador Nacional do Sistema Elétrico (ONS), Brasil).

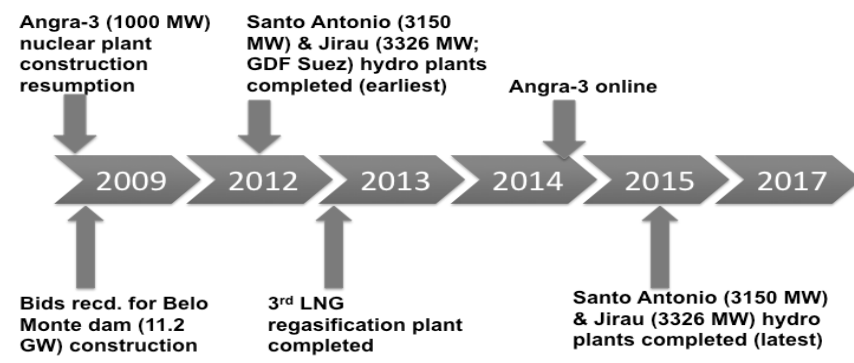

Figure 6. A short-term timeline of generation capacity additions in Brazil (figure generated with data from [14], [17]).

The electric transmission system in Brazil is expected to significantly expand in tandem with the generation capacity additions [18]. This is enabled by the Growth Acceleration Plan (PAC) -a plan that provides progressively lowering rates of interest for energy sector investments such as in transmission systems [19]. So, unlike in the US, the electricity infrastructure in Brazil is expected to grow in all sectors, viz., generation, transmission, and distribution.

\section{COMMON LESSONS ON GRID MODERNIZATION IN THE US AND BRAZIL}

The official policy of grid modernization in the US is expected to impact the distribution realm of the electricity delivery infrastructure in the US [11]. The Smart Grid Initiative in the US is also expected to impact the generation side of the infrastructure particularly with respect to the integration, operation and control of renewable resource and energy storage elements. It is not apparent that the Smart Grid Initiative may lead to infrastructure growth in the transmission systems in the US beyond installations of phasor measurement units (PMUs) and wide-area measurement systems (WAMS). This may be even more apparent given the challenges facing infrastructure developments vis-à-vis location, siting, cost allocation, and interstate regulations in the transmission system in the US. In late 2009, the US DoE awarded approximately $\$ 3.4$ billion to various entities in US for deploying and demonstrating the Smart Grid concept via innovative enhancements to the grid such as pervasive smart meter installations, smart appliances, demand response pilot programs, etc. [20].

The Brazilian electricity infrastructure, unlike that of the US, is expected to grow in all sectors, viz., generation, transmission, and distribution. The challenge in electricity infrastructure growth in a developing nation like Brazil is inherently tied to social and economic growth [21], [22]. Even while the electricity grid infrastructure is being expanded, there may be new, hitherto unconsidered environmental constraints that may play a significant role considering the fact that Brazil is the only South American country in the list of top twenty fossil fuel $\mathrm{CO}_{2}$ emitters and that the Amazon region in Brazil is projected to have over $100 \mathrm{GW}$ of undeveloped hydro-potential [23], [24].

Perhaps the most significant impact under the lens of the Smart Grid Initiative with regard to the Brazilian electricity infrastructure may relate to cross-border trades and market regulations [24]. It is believed that with reform such as timeof-use tariffs, efficiency can be boosted through demand response [25]. This may be achieved through the active participation by customers enabled by technologies such as smart meters. In Brazil, a surge in smart meter and automated metering infrastructure (AMI) has recently been reported [26], [27], [28].

PMUs hold the promise of increasing transmission reliability through better real-time monitoring and situational awareness, helping create better models of physical systems using post-event data [29]. There are already 2 installations of PMUs in the Brazilian national interconnected system (NIS) for real-time and offline applications [30]. These installations may prove very useful in understanding the signature of the events that lead to the blackout of the Brazilian grid on November 10, 2009. In the Brazilian transmission network, PMU installations are expected to accelerate, especially after the abovementioned wide-area blackout of 2009.

Based on the foregoing discussion, a comparative snapshot between the tenets of the US Smart Grid Initiative and the possible applications in the Brazilian electricity infrastructure may be drawn; this is shown in Table 1. 
TABLE 1. A COMPARATIVE SNAPSHOT OF THE RECOMMENDATIONS OF THE SMART GRID INITIATIVE AND ITS APPLICABILITY TO THE BRAZILIAN ELECTRICITY INFRASTRUCTURE.

\begin{tabular}{|c|c|}
\hline $\begin{array}{l}\text { Smart Grid Initiative } \\
\text { recommendation }\end{array}$ & $\begin{array}{l}\text { Applicability to the Brazilian electricity } \\
\text { infrastructure }\end{array}$ \\
\hline $\begin{array}{l}\text { Use of digital controls and } \\
\text { information }\end{array}$ & $\begin{array}{l}\text { Basic tenet aimed at improving reliability } \\
\text { and efficiency of grid. }\end{array}$ \\
\hline $\begin{array}{l}\text { Dynamic optimization and cyber } \\
\text { security of grid }\end{array}$ & $\begin{array}{l}\text { Needed for security of supply, especially } \\
\text { in the light of scarcity of supply from } \\
\text { hydropower due to drought, [15], and } \\
\text { recent (but unconfirmed) reports of } \\
\text { hacking in the Brazilian electricity grid } \\
\text { [31]. }\end{array}$ \\
\hline $\begin{array}{l}\text { Widespread DER deployment } \\
\text { including renewables }\end{array}$ & $\begin{array}{l}\text { Wind is expected to grow at } 14.8 \% \\
\text { annually from '09-' } 30 \text { [14]; this is } \\
\text { expected to herald new installations, } \\
\text { operation and control philosophies, and } \\
\text { enable markets for renewables. }\end{array}$ \\
\hline $\begin{array}{l}\text { Use of demand response and } \\
\text { peak shaving }\end{array}$ & $\begin{array}{l}\text { Demand response based on tariffs may } \\
\text { introduce greater efficiency in energy } \\
\text { consumption in Brazil [25]. This may } \\
\text { lead to efficient philosophies for tiding } \\
\text { over times of severe drought as well. }\end{array}$ \\
\hline $\begin{array}{l}\text { Smart appliances and } \\
\text { technologies }\end{array}$ & $\begin{array}{l}\text { Increasing installations of enabling } \\
\text { technologies such as smart meters and } \\
\text { AMI may lead to better strategies for } \\
\text { demand response; PMUs and WAMS } \\
\text { may hold the key to modernizing the } \\
\text { expanding transmission system in Brazil. }\end{array}$ \\
\hline Customer-driven & $\begin{array}{l}\text { This aspect of active participation of } \\
\text { customers in demand response holds the } \\
\text { promise of enhanced energy efficiency. }\end{array}$ \\
\hline Standards for interoperability & $\begin{array}{l}\text { As in the US and in Europe where Smart } \\
\text { Grid initiatives are underway, a major } \\
\text { requirement in Brazil with regard to } \\
\text { deployment of dispersed technologies } \\
\text { may be the development of standards for } \\
\text { interoperability. }\end{array}$ \\
\hline
\end{tabular}

\section{CONCLUSIONS}

This paper aimed at presenting some contemporary efforts on electricity grid modernization in USA and Brazil and attempted to draw commonalities and differences in those efforts under the lens of the Smart Grid Initiative, a federal policy of modernizing the US electricity grid.

\section{ACKNOWLEDGMENT}

S. Suryanarayanan gratefully acknowledges the questions and discussions from the audiences at his presentations in November 2009 on the topic of this paper at the Universidade Federal de Santa Catarina, Florianópolis, SC, Brazil, and the panel at the $15^{\text {th }}$ Intelligent System Applications in Power Systems Conference, Curitiba, PR, Brazil, that greatly helped shape the material contained here. S. Suryanarayanan and M. G. Simões acknowledge the support of the Center for Advanced Control of Energy and Power Systems (ACEPS) at Colorado School of Mines.

\section{REFERENCES}

[1] (Nov 2009) "Major power failures hit Brazil." British Broadcasting Company (BBC) News. [Online]. Available: http://news.bbc.co.uk/2/hi/americas/8353878.stm (Accessed: Nov 2009).

[2] (Nov 2009) "Brazil insists short circuit, bad weather caused blackout." AFP. [Online]. Available:
http://www.google.com/hostednews/afp/article/ALeqM5g851TKVOIDV qmC3jEIueUid8cGAg (Accessed: Nov 2009).

[3] (Apr 2004) "Final report on the August 14, 2003 blackout in the United States and Canada: Causes and recommendations." US-Canada Power System Outage Task Force. [Online]. Available: https://reports.energy.gov/BlackoutFinal-Web.pdf (Accessed: Nov 2009).

[4] $110^{\text {th }}$ Congress of the United States of America. "Title XIII: Smart Grid Initiative," Energy Independence and Security Act of 2007, Dec 2007.

[5] "Smart grid" Office of Electricity Delivery and Energy Reliability, US Dept. of Energy. [Online]. Available: http://www.oe.energy.gov/smartgrid.htm (Accessed: Nov 2009).

[6] (Mar 2009)“Annual energy outlook 2009 with projections to 2030.” Energy Information Administration. [Online]. Available: http://www.eia.doe.gov/oiaf/aeo/electricity.html (Accessed: Sep 2009).

[7] (Jul 2003) "GRID 2030": A national vision for electricity's second 100 years. [Online]. Available: http://climatevision.gov/sectors/electricpower/pdfs/electric vision.pdf (Accessed: Nov 2009).

[8] (Apr 2008) D.K. Owens, "Electricity: 30 years of industry change," [Online]. Available: http://www.eia.doe.gov/conf pdfs/Monday/owens.pdf (Accessed: Nov 2009).

[9] (Mar 09) B. L. Dorgan. "The case for a $21^{\text {st }}$ century electricity transmission system." Democratic Policy Committee. [Online]. Available: http://dpc.senate.gov/dpcdoc.cfm?doc_name=fs-111-1-34 (Accessed: Nov 2009).

[10] (Sep 09) I. Talley. "Interior department to approve seven renewableenergy projects" Wall Street Journal. [Online]. Available: http://online.wsj.com/article/SB125434790460153875.html (Oct 2009).

[11] D. Moore, D. McDonnell, "Smart grid vision meets distribution level reality," Marietta, GA: The McDonnell Group, Inc., Mar 2007.

[12] (2009) "Brazil: The World Factbook" Central Intelligence Agency (CIA). [Online]. Available: https://www.cia.gov/library/publications/theworld-factbook/geos/br.html (Accessed: Nov 2009).

[13] G. Volpi, G. Jannuzzi, R. D. M. Gomes, "A sustainable electricity blueprint for Brazil," Energy for Sustainable Development, v. X, no. 4, Dec 2006, pp. 14-24.

[14] (May 2009) "International energy outlook 2009." Energy Information Administration. [Online]. Available: http://www.eia.doe.gov/oiaf/ieo/electricity.html (Accessed: Nov 2009).

[15] (Nov 2009) E. Simoes. "Lula seeks explanation for huge Brazilian blackout." Thomson Reuters Foundation. [Online]. Available: http://www.alertnet.org/thenews/newsdesk/N11359862.htm (Accessed: Nov 2009).

[16] (May 2009) R. Polito. "Uranium-based expansion." Brasil energy, [Online].

Available: http://www.energiahoje.com/brasilenergy/2009/08/05/389909/uraniumbased-expansion.html (Accessed: Oct 2009).

[17] (May 2009) "Brazil infrastructure report Q2." Business Monitor Int'1. [Online]. Available: http://www.the-infoshop.com/report/bmi92818brazil-infrastructure-2.html (Accessed: Nov 2009).

[18] L. A. Barroso, J. M. Bressane et al., "Transmission structure in Brazil: organization, evaluation \& trends," in Proc. 2004 IEEE PES General Meeting, Denver, CO, [Online]. Available: http://www.ieee.org/portal/cms_docs_pes/pes/subpages/meetingsfolder/2004_Denver/Track1/Pres_4-Brazil.pdf (Accessed: Nov 2009).

[19] "Growth acceleration plan (PAC)- Better credit conditions to infrastructure." Brazilian development bank [Online]. Available: http://inter.bndes.gov.br/english/pac.asp (Accessed: Nov 2009).

[20] US Department of Energy. Recovery act selections for Smart Grid Investment Grant awards - by state. [Online] \{Available\} http://www.energy.gov/recovery/smartgrid_maps/SGIGSelections_State. pdf (Accessed: Oct 2009).

[21] S. Mocarquer, L. Barroso, H. Rudnick, B. Bezzera, M. Pereira, "Balance of power," IEEE Power \& Energy Magazine, v. 7, no. 5, pp. 27-35, Oct 2009.

[22] (Jun 2008). A. Y. Zheng. "How the Smart Grid is opening up Latin American opportunities." SmartGridNews. [Online]. Available: http://www.smartgridnews.com/artman/publish/industry/How_the_Smar t Grid Is Opening Up_Latin American Opportunities.html (Accessed: Nov 2009).

[23] L. Barroso, S. Mocarquer, H. Rudnick, T. Castro, "Creating harmony in South America," IEEE Power \& Energy Magazine, v. 4, no. 4, pp. 3346, Aug 2006. 
[24] H. Rudnick, L. Barroso, C. Skerk, A. Blanco, "South American reform lessons," IEEE Power \& Energy Magazine, v. 3, no. 4, pp. 49-59, Aug 2005.

[25] "Brazil- Energy and power." Encyclopedia of the Nations. [Online]. Available: http://www.nationsencyclopedia.com/Americas/BrazilENERGY-AND-POWER.html (Accessed: Nov 2009).

[26] (Jun 2009) L. Maurer. "Tariff schemes to foster demand response (DR) = energy efficiency and demand side management (DSM)." [Online]. Available:

http://www.aneel.gov.br/arquivos/PDF/Luiz\%20Maurer_Jun09_AneelSe minar_eng.pptx.pdf (Accessed: Oct 2009).

[27] (Jul 2009) "Brazil selects first approved smart meter systems provider." Metering.com. [Online]. http://www.metering.com/node/15639 (Accessed: Nov 2009)

[28] (Oct 2009) H. Lamin. "ANEEL reveals tentative plans for smart metering in Brazil." Metering.com. [Online]. Available: http://www.metering.com/node/16407 (Accessed: Nov 2009).

[29] (Sep 2006) R. Moraes. "Business case: Justification for Brazilian PMU system." [Online]. Available: http://phasors.pnl.gov/Meetings/2006_september/tuesday/Justification_f or_Brazil_PMU\%20System.pdf (Accessed: Oct 2009).

[30] H. Volskis, R. M. de Moraes, "WAMS initiatives in Brazil," in The wide world of wide-area measurement, A. G. Phadke, Ed., IEEE Power \& Energy Magazine, v. 6, no. 5, pp. 52-65, Oct 2008.

[31] (Nov 2009) "Cyber war: Sabotaging the system; 60 Minutes: Former chief of national intelligence says US unprepared for cyber attacks." CBS News. [Online]. Available: http://www.cbsnews.com/stories/2009/11/06/60minutes/main5555565.sh tml (Accessed: Nov 2009).

\section{BIOGRAPHIES}

S. Suryanarayanan (S'00-M'04-SM'10) is from Chennai, India. He holds the $\mathrm{Ph}$.D. degree in electrical engineering from Arizona State University, Tempe,
AZ. He held research appointments in the faculties of Arizona State University and Florida State University and is currently an Assistant Professor of Engineering at the Colorado School of Mines, Golden, CO. He teaches and performs sponsored research in the area of advanced electric power systems.

P. F. Ribeiro (M'78-SM'88-F'03) received the B.S. degree in electrical engineering from the Universidade Federal de Pernambuco, Recife, Brazil and the Ph.D. degree from the University of Manchester, Manchester, U.K. Currently, he is a Professor of Engineering at Calvin College, Grand Rapids, MI.

M. G. Simões (S'89-M'95-SM'98) received the B.S. and M.Sc. degrees in electrical engineering from the University of São Paulo, São Paulo, Brazil, in 1985 and 1990, respectively, the Ph.D. degree in electrical engineering from the University of Tennessee, Knoxville, in 1995, and the Livre-Docencia (D.Sc.) degree in mechanical engineering from the University of São Paulo, in 1998. He joined Colorado School of Mines, Golden, where he has been engaged in establishing research and education activities in the development of intelligent control for high power electronics applications in renewable and distributed energy systems. He has authored the books Renewable Energy Systems: Design and Analysis With Induction Generators (CRC Press) and Integration of Alternative Sources of Energy (Wiley/IEEE Press).

Dr. Simões is the recipient of the National Science Foundation (NSF) Faculty Early Career Development (CAREER) in 2002, the NSF's most prestigious award for new faculty members. He is serving IEEE in several capacities and is currently an Associate Editor of the IEEE TRANSACTIONS ON POWER ELECTRONICS and the Chair for the IEEE Industry Applications Society (IAS) Industry Automation Control Committee (IACC). He is the director of the Center for Advanced Control of Energy and Power Systems (ACEPS), a research center at Colorado School of Mines. 